Georgia State University

ScholarWorks @ Georgia State University

World Languages and Cultures Faculty

Publications

Department of World Languages and Cultures

2020

\title{
Quality Videos and Integrated Performance Assessments Are Essential in the World Language edTPA
}

\author{
Peter Swanson \\ Georgia State University, peters@tribcsp.com \\ Jean W. LeLoup \\ United States Air Force Academy, leloupj@snycorva.cortland.edu
}

Follow this and additional works at: https://scholarworks.gsu.edu/mcl_facpub

Part of the Other Languages, Societies, and Cultures Commons

\section{Recommended Citation}

Swanson, P., \& LeLoup, J. W. (2020). Quality Videos and Integrated Performance Assessments Are Essential. In M. Khosrow-Pour (Ed.), Handbook of Research on Modern Educational Technologies, Applications, and Management (pp.124-138). Hershey, PA: IGI Global.

This Book Chapter is brought to you for free and open access by the Department of World Languages and Cultures at ScholarWorks @ Georgia State University. It has been accepted for inclusion in World Languages and Cultures Faculty Publications by an authorized administrator of ScholarWorks @ Georgia State University. For more information, please contact scholarworks@gsu.edu. 


\title{
Quality Videos and Integrated Performance Assessments Are Essential in the World Language edTPA
}

\author{
First Author: Pete Swanson, Ph.D. \\ United States Air Force Academy, USA \\ United States of America
Second Author: Jean W. LeLoup, Ph.D.
United States Air Force Academy, USA
United States of America

\begin{abstract}
For more than 60 years, educational reform in the United States of America has been driven by four major questions revolving around teacher attributes, effectiveness, knowledge, and outcomes. Today, outcomes for not only students but also for those who teach them have become a focal point. The purpose of this chapter is to discuss the World Language edTPA - a performance-based, subject-specific assessment for pre-service teachers in 27 content areas that is now in place in 41 states and the District of Columbia. The authors begin by highlighting educational policy and best practices in teaching languages before providing research-based suggestions regarding the development of a high-quality portfolio by focusing on video recording considerations and the use of the integrated performance assessment.
\end{abstract}

\section{INTRODUCTION}

For decades teacher education has been under siege (Swanson, 2017), and teacher preparation in the United States continues to be in educational reformers' crosshairs more than ever these days (Cochran-Smith, 2000). While the Trump administration has focused largely on financial and geopolitical issues, teacher preparation has been the focus since the 1960s when President Lyndon B. Johnson introduced legislation known as the War on Poverty, which Congress passed into law as the Elementary and Secondary Education Act of 1965 (ESEA) in 1965 (P.L. 89-10. With such massive impact, the ESEA act essentially jump-started the next 60 years of educational reform in the United States (US). CochranSmith (2000) advanced the notion that since the mid-1950s educational reform can be documented in terms of four major driving questions: teacher attributes, effectiveness, knowledge, and outcomes. She 
noted that the political climate shaped the order in which these questions emerged, the kind and degree of public attention afforded to $\mathrm{K}-12$ education, the demand for and supply of teachers, state and federal policies regarding funding, and even perceptions of teacher education as a profession.

\section{Attributes}

Beginning with the Eisenhower administration through the 1960s, the Attributes question inquired about the characteristics and of potential teachers, qualities of good teachers and teacher education programs at the time when President Eisenhower and other world leaders noted a severe shortage of language teachers (Swanson, 2012). In terms of teaching world languages (WL), there were few empirical studies focused on language teachers. Researchers investigated the personal characteristics of teachers; and those that trained them, such as having a friendly voice free of a strong foreign accent and good pronunciation based on accepted standards of usage (Los Angeles City Schools 1963). Language teaching organizations such as the Modern Language Association promoted the notion that language teachers must be able to command the target language (TL), and they must have factual and conceptual knowledge from various disciplines as well as strong pedagogical knowledge (Axelrod, 1966).

\section{Effectiveness}

From the late 1960s through the first Reagan administration in the 1980s, a shift of focus began to emerge with a focus on examining the attributes of teachers and preparation programs. The emphasis on studying teacher and preparation program attributes was replaced with what it means to be an effective instructor. Questions revolved around effective teaching processes and strategies and what teacher education processes were most effective in ensuring that pre-service teachers learn these strategies. Researchers placed attention on effective teaching processes and strategies and what teacher education practices were the most successful in confirming that pre-service teachers learn and use these strategies. It was at this time that many teacher preparation programs invested in and developed systems for evaluating pre-service teachers according to certain objectives as well as performance criteria (Gage, 1972).

With respect to language teaching, for example, WL program improvement was developed for Indiana colleges and universities focusing on five stages: (1) identifying practices in foreign language 
(FL) methods in colleges and universities, (2) creating dialogue among methods teachers, (3) enlisting administrator and cooperating teacher support, (4) establishing priorities from the Guidelines for Teacher Education Programs in Modern Language, and (5) developing seminars on content, materials, and teaching practices for methods courses in world language teaching (Strasheim, 1967). Other research focused on comparing the effectiveness of different language teacher preparation programs (McInnis \& Donoghue, 1980)

\section{Knowledge}

From the midpoint of the Reagan administrations in the 1980s and continuing through the Clinton administrations in the 1990s, governmental, and later public, concern about teacher education and teacher quality became the focus (Cochran-Smith, 2000) with the publication of A Nation at Risk (National Commission on Excellence in Education, 1983) — a scathing portrayal of the American educational system. Reform reflected a shift from what effective teachers do to focus on what they know, and perhaps even more important, what they need to know and be able do. Additionally, questions revolved around what the teacher knowledge base should be. Research on WL teaching and learning, for example, focused on comparative analyses of expert WL teachers' reflective-narrative discourse (Olshtain \& Kupferberg, 1998) and pedagogical knowledge (Gatbonton, 1999).

\section{Outcomes}

Arguably what can be considered one of the most debated educational topics of the new millennium is the Outcomes Question — "how to measure and demonstrate the outcomes of teacher education" (Cochran-Smith, 2000, p. 18). Policy makers at all levels and educational testing companies began to formulate questions about "how we should conceptualize and define the outcomes of teacher education for teacher learning, professional practice, and student learning, as well as how, by whom, and for what purposes these outcomes should be documented, demonstrated, and/or measured" (CochranSmith, 2001, p. 1). The question's foundation posits that the definitive goal of teacher education is student learning, and that there are certain objective measures that can be used to determine the degree of success 
or failure for learners, pre-service teachers, teacher education programs, and institutions of higher education that prepare teachers (Cochran-Smith, 2000).

Noting the educational landscape of the Outcomes question, the Stanford Center for Assessment, Learning, and Equity (SCALE, n. d.) began to develop edTPA as a "uniform and impartial process to evaluate aspiring teachers" (p. 1). After working directly with teachers and teacher educators along with drawing from experience "gained over 25 years of developing performance-based assessments of teaching (including the National Board for Professional Teaching Standards, the InTASC Standards portfolio, and the Performance Assessment for California Teachers)" (p. 1), this high-stakes assessment of beginning teacher readiness was developed, pilot tested in the field, refined, and ultimately branded for use. Early research on the WL edTPA highlighted serious problems with the portfolio, (Hildebrandt \& Swanson, 2014), especially in the area of assessment of student learning. In this chapter, the authors present edTPA in the context of world languages (WLs) and then discuss the importance of two facets of creating a highquality WL edTPA portfolio.

\section{BACKGROUND}

As advanced by legislation at the local, state, and national levels since the introduction of the ESEA act in 1965, the goal for education in the US is improving student learning for all students. While Muijs (2006) noted that such a goal remains challenging, it is without a doubt that the measurement of teacher effectiveness is a critical component of reaching such a lofty objective.

\section{Teacher Portfolio Assessment}

For decades, "teachers have been increasingly required to prove that they have demonstrable teaching competencies" (Hammadou-Sullivan, 2004, p. 390), and portfolios have served as a medium for such assessment. A review of the literature suggests that there is a quandary as to what to include in a teaching portfolio, which can be particularly challenging for WL teachers (Hammadou-Sullivan, 2004) because administrators that seek to hire these novice teachers have little to no experience in teaching and learning a second language (L2). Wright, Knight, and Pomerleau (1999) suggested at the turn of the century that there was a "lack of good research evidence about their impact" (p. 92). 
Nevertheless, pre-service teacher candidates' performance was measured via portfolio assessments. At the turn of the century, pre-service teachers created an assessment plan, provided evidence of instructional decision-making, gathered and interpreted student data, demonstrated that they used student learning assessment data to adjust their teaching, and communicated with others about students' progress via The Teacher Work Sample (Renaissance Partnership for Improving Teacher Quality, 2002). A few years later, researchers designed the Performance Assessment for California Teachers (PACT) in order to measure a teacher candidate's knowledge, skills and abilities to teach and assess K-12 students (Sato, 2014). Grounded in the National Board for Professional Teaching Standards for veteran teachers, the PACT served as the basis for the development of edTPA (Sato, 2014.)

\section{edTPA}

As noted earlier, edTPA was developed by SCALE, pilot tested in several states beginning in 2011, and marketed as a nationally-available performance assessment of novice educators' readiness to teach in 27 different content areas (SCALE, 2013). Collaborating with the American Association of Colleges for Teacher Education and administered online by Pearson, edTPA is administered across institutions and states and reliably scored by experts in teaching (Sato, 2014). Presently, edTPA is in various stages of implementation in 854 educator preparation programs in 41 states and the District of Columbia (American Association for Colleges of Teacher Education, 2019) in order to inform initial teacher licensure and certification decisions. For example, in the state of Alaska there is at least one educational provider exploring edTPA's use as a performance-based assessment at present. In other states such as Georgia and Illinois, edTPA was being pilot tested beginning in 2012 and became a requirement for certification in September 2015.

In most cases, pre-service teachers create their portfolios during their final field placement, also known as student teaching. The portfolio centers on three tasks: (1) Planning for Instruction and Assessment, (2) Instructing and Engaging Students in Learning, and (3) Assessing Student Learning. Success on the WL edTPA is measured by thirteen 5-point Likert-scale rubrics. The 5-point scale describes a person's pedagogical knowledge and skills on a continuum ranging from teacher candidates 
who are not ready to teach to being very well-qualified individuals to teach (SCALE, 2013). A teacher candidate's total score can range between 13 to 65 points. Given that individuals creating an edTPA portfolio are novice educators at best, they are not expected to be in the advanced range of the rubrics (i.e. earning scores of 4 and 5 on the rubrics).

As noted by SCALE (2019A), "states may set their own passing scores based on state standardsetting panels that take into account state-specific data, measurement data, and state's policy considerations" (p. 1). While official cut scores for edTPA have yet to be set at the national level, individual states have established cut scores that currently range between 32 and 35 for the WL edTPA (SCALE, 2017). For example, a cut score of 29 for the WL edTPA was set in Georgia for Fall 2015 enactment (Georgia Professional Standards Commission, GAPSC, 2015). And each year the score can be increased. In 2019, the required score in Georgia increased to 32 for WL teacher candidates (SCALE, 2019).

Early research on the WL edTPA in two programs, one in Georgia and one in Illinois, indicated that of the three tasks, teacher candidates "were most successful in the planning tasks and least successful in the assessment tasks" (Hildebrandt \& Swanson, 2014, p. 584). The researchers stated that such findings may be explained by typical curricula in WL teacher preparation programs. That is, while pre-service teachers spend substantial time on developing pedagogical prowess and even have opportunities to teach lessons with students in K-12 schools when placed in schools for practicum placements and student teaching, very infrequently are they creating assessments and analyzing student performance data. During field placements like student teaching, these individuals most likely have access to K-12 student data because they are in charge of the classroom typically. However, it is during this time when they are creating their edTPA dossiers. Thus, prior to student teaching, teacher candidates do not have sufficient opportunities to collect and analyze data, which is required by edTPA. By the time they have access to student data, the researchers posit that it is too late for them to learn how to analyze data and determine a course of action for later instruction. 


\section{BEST PRACTICES IN WORLD LANGUAGE ASSESSMENT OF STUDENT LEARNING}

The teaching and learning of WLs has seen a paradigm shift in recent years. This shift has moved language instruction away from adherence to strict grammar translation, the audio-lingual approach, and other methodological emphases toward the current belief that language learners need and want to engage in activities that involve significant TL communication (Shrum \& Glisan, 2016). Once known as teaching the four skills (i.e., reading, writing, listening, and speaking) in the TL, WL instruction and assessment is now conceptualized in the communicative language teaching (CLT) approach that places the emphasis on language function rather than form (Nunan, 1991). Learners want to be able to use the language rather than merely learn about the language. To that end, CLT promotes instruction that primarily incorporates activities using the TL in myriad authentic tasks that learners recognize as real-life possibilities and situations (Lee \& VanPatten, 2003). Buttressed by the position statement of the American Council on the Teaching of Foreign Languages (ACTFL, 2010) stating that the classroom goal should be $90 \%$ TL use by both teachers and learners, CLT has revolutionized how instruction in language classrooms is conceptualized and carried out.

This paradigm shift has generated a ripple effect spreading from the classroom back to teacher preparation programs, as pre-service language teachers must be prepared to focus their instruction on developing student communicative proficiency in the language. In other words, pre-service FL preparation needs to include CLT as a mainstay of pedagogical content knowledge for teacher candidates (Garcia, Moser, \& Davis Wiley, 2019; Hlas, 2016; Larsen-Freeman \& Tedick, 2016). This is a tall order for several reasons. First, the field of FL education can be slow to change-witness the time it has taken for CLT to take hold and be substantiated by research. Despite evidence to the contrary, many FL practitioners persist in teaching about the language or offer L2 instruction in the students' first language (L1). Second, most teacher preparation programs are typically two years in length and may only include a FL methods course of one semester duration. It is little wonder with such a limited timeline and base that many pre-service teachers fall back on the known and resort to teaching how they were taught 
(Martel, 2017; Swanson \& Hildebrandt, 2017). Nevertheless, successful CLT requires specific teacher candidate preparation, focus, and a new approach to assessment of language learning, all of which must begin in pre-service teacher education programs.

The implementation of CLT has engendered a focus on the three modes of communication: interpretive, interpersonal, and presentational (World-readiness Standards for Foreign Language Learning, 2015). In other words, language learners are asked to engage in TL communication in one or more of these modes on a regular basis. Concomitantly, along with the attention to communicative language activities, current best practices in language teaching for proficiency in the TL place an emphasis on developing and demonstrating this proficiency through performance-based assessments.

\section{Student Proficiency Assessment in the Target Language}

Performance-based assessments reflect the tasks and challenges language learners will face in real world scenarios. Through such assessments, students can work individually or collaboratively, use their collection of skills and knowledge to create a response to a prompt (complex questions or situations) or a product that can have more than one correct response (Liskin-Gasparro, 1996, 1997; Wiggins, 1998). The Integrated Performance Assessment (IPA) serves as an evaluation of student ability in the TL that is used as a cluster assessment featuring several activities (Adair-Hauck, Glisan, Koda, Swender, \& Sandrock, 2006). The IPA was inspired by social constructivist theories of learning and conceived as a standardsbased practical way to assess the success of L2 learners on performance-based tasks developed to measure the outcomes espoused by the World-readiness Standards of ACTFL (Adair-Hauck, \& Troyan, 2013; Kissau \& Adams, 2016; Zapata, 2016).

The IPA is a multi-task assessment conceptualized within a single thematic context. The assessment includes a series of assignments that mirror the three modes of communication and one or more other standards (e.g., cultures). These tasks may be carried out over several class periods (Cox, Malone, \& Winke, 2018). For example, language learners first complete an

[INSERT FIGURE 1 APPROXIMATELY HERE] 
interpretive task (e.g., reading or watching a video). Afterwards, they employ the information from an interpersonal task (e.g., conversation) before they summarize their learning with a presentational task. That is, language learners listen to, view, and/or read authentic texts in the TL, interact with learners in the TL in written and oral form, and then present orally and/or in written form to an audience. Feedback on each portion of the IPA can help students set new learning goals as well as directing teachers toward more proficiency-oriented instruction (Cox et al., 2018; Kissau \& Adams, 2016; Martel \& Bailey, 2016). The IPA is a well-established model of performance-based assessment of student language proficiency. Its adoption does represent a significant philosophical and pedagogical shift in instruction for language departments. Hence, it is incumbent upon pre-service teacher educators to incorporate knowledge, implementation of, and evaluation of IPA materials, purposes, tasks, rubrics, and their appraisal in the FL methods course (Kaplan, 2016; Okraski \& Kissau, 2018). Furthermore, it has been shown that teacher candidates who implement an IPA as part of their WL edTPA portfolio score higher than those who choose to document traditional measures of learner assessment (Swanson \& Goulette, 2018).

\section{USING VIDEO AND VIDEO CONSIDERATIONS}

\section{Teacher Candidate Skills Using Video}

Today's teacher candidates who will be developing an edTPA portfolio typically have a broad skillset using technology. Some have even acquired specialized skills to integrate technology in the classroom. However, many have never used video as a self-reflective practice to watch themselves after they have taught a lesson (Goulette \& Swanson, 2017). While it may make pre-service teachers anxious watching themselves teach, researchers find that video recording is a worthwhile pedagogical tool for self-reflection and growth as an educator (e.g., Baecher, McCormack, \& Kung, 2014; Danielowich \& McCarthy, 2013).

Throughout the US, teacher preparation program curricula vary to the degree and emphasis of technology integration. Some teacher preparation programs have a dedicated technology course (e.g., Georgia State University) and other programs embed technology throughout the program (e.g., Illinois State University). Regardless of this, having the skills to successfully record oneself and gaining consent 
from parents / guardians for their children to be video recorded are necessary when creating an edTPA portfolio.

\section{Securing Parental / Guardian Consent}

As part of edTPA, teacher candidates must turn in a video of them working with learners in the classroom. Each teacher candidate selects a focal class on whom to focus their efforts and must receive parental / guardian permission to film in class even though their children may or may not appear in the video. If a parent / guardian refuses to grant permission, the student can still reside in the classroom for instruction but may not appear in the video unless his/her face is blacked out digitally. Thus, securing prior parental / guardian consent for recording in the focal class that has been selected is a prerequisite for edTPA. Teacher program coordinators need to make sure that school administrators and cooperating teachers will allow teacher candidates to film the focal class during class time. Otherwise, there is no need for a teacher candidate to be placed in a school with a teacher only to find out that video recording is not allowed. Researchers have advocated that once the focal class is identified, it is imperative that teacher candidates begin securing parental / guardian permission for their children to be video-recorded (Hildebrandt \& Swanson, 2016). Given such a requirement, teacher preparation programs have created permission forms for teacher candidates to use for edTPA purposes. Interestingly, although some school districts require parents/guardians to sign a consent form for video recording at the start of each academic year, many times such a form may not include recording for edTPA purposes.

With respect to the recording, it is recommended that teacher candidates designate two distinct classroom sections temporarily: one section for the learners who can appear in the video and another section for those who lack parental / guardian permission, which is outside of the camera's view. In this scenario, a tripod can be a useful instrument to focus on one section while excluding the other section from the video. Using such an approach allows for the teacher candidate to engage all learners while the camera only focuses on those students whose parents / guardians have consented. It is recommended that the teacher candidate pilot test the placement of the camera not only so that the video area is correct, but also so that the audio can be heard from people furthest away in the classroom. 


\section{Minimizing Teacher Candidate Anxiety}

As one might imagine, teacher candidates are typically most anxious during the recording phase of the edTPA. There are myriad reasons why the video recording process and submission can be anxietyprovoking for these novice teachers. These reasons range from potential technical problems to less than optimal TL proficiency concerns to insufficient pedagogical training and background in developing, executing, and evaluating student performance on the IPA tasks (Cox et al., 2018; Kissau \& Adams, 2016; Tum, 2015). A pre-service teacher's personal insecurity about TL proficiency could certainly cause the candidate to experience anxiety when approaching the video recording task. Such anxiety could even affect the candidate's performance and even percentage of use of the TL during the lesson. Although much research has concentrated on learner anxiety, teacher FL anxiety is also a serious concern because it can have profound implications for what happens in the classroom. A pre-service teacher with self-doubts about TL proficiency may choose, consciously or unconsciously, to avoid TL use as much as possible, thus calling into question the quantity and/or quality of TL input the learners receive. This, in turn, may have a domino effect on future learners who become language teachers themselves (Horwitz, 2010; Tum, 2015).

In terms of pre-service teacher preparation for developing, administering, and evaluating appropriate tasks for IPAs, several studies have revealed that teachers do struggle to prepare and execute IPAs that assess student proficiency in a balanced way across the communicative modes. Indeed, it seems that such preparation should be a necessity in teacher education programs, given that IPAs appear to be gaining in favor (Cox et al., 2018; Garcia et al., 2019; Kaplan, 2016; Kissau \& Adams, 2016). The edTPA assessments require strong support from these preparatory programs. Perhaps a repository of sample IPAs could be developed to serve as professional resources for pre-service and in-service teachers alike (Martel \& Bailey, 2016; Okraski \& Kissau, 2018).

As a gauge of teacher candidate anxiety relating to technological problems, students in the Georgia State University FL education program who recently completed the edTPA reported the following concerns about the recording phase: technological issues, such as ensuring that the camera's 
batteries are sufficient to record the entire class period; students' sensitivity to the camera, for example, students misbehaving to show off for the camera; the pressure to produce the best quality video of excellent teaching that is highly engaging to students; and factors outside of their control that could come to bear on the video recording process, such as fire drills or other interruptions that could negatively affect the instruction. While these potential issues cannot be completely mitigated, university supervisors and cooperating teachers in the K-12 schools can collaboratively assist teacher candidates by offering suggestions based on past experiences working with video cameras in the classroom for edTPA. Again, early efforts in self-videotaping is a useful practice to help acclimatize pre-service teachers to the demands of video recording, its pitfalls and potentials.

\section{Vital Considerations for Video Recording}

The authors recognize that there are common technical issues that teacher candidates may deal with when building an edTPA portfolio. Thus, it is recommended that teacher candidates become familiar with the edTPA website, especially in terms of the recording process. As noted by Goulette and Swanson (2017), it is important that teacher candidates become familiar with video recording equipment well before beginning an edTPA portfolio. Such familiarity will most likely reduce teacher candidate anxiety and assist candidates in becoming more confident using the technology and even appearing in a video. The authors encourage teacher candidates to film themselves teaching as much as possible in order to be able to observe themselves critically. These videos can also be useful in monitoring general teaching behaviors such as inclusive presence (e.g., addressing all students the majority of the time), distracting mannerisms (e.g., playing with hair or a pen), and - arguably most important in a world language classroom-TL use.

When video recording for the edTPA portfolio, teacher candidates must turn in recordings of no more than fifteen minutes in either one clip or two clips that must be less than $300 \mathrm{MB}$ total in size. The target size is 200-300 MB or less (Pearson, 2014). Such a video size requirement means that teacher candidates should film in standard definition instead of high definition in order to keep file size smaller. Pearson recommends shooting video in the landscape aspect ratio and having resolution set to either $320 \mathrm{x}$ 
240 or 640 x 480. Additionally, edTPA only accepts video files in flv, .asf, .qt, .mov, .mpg, .mpeg, .avi, $. w m v, . m p 4$, and.$m 4 v$ formats (Pearson, 2014). These are ubiquitous video file formats that can be opened by external reviewers who may use a variety of computers. Nevertheless, before submitting video files, the authors strongly recommend that teacher candidates try to open their video files on several different computers to avoid a potential issue with the external reviewers not being able to open and view their videos. In the event that the video cannot be seen/heard, the teacher candidate does not receive a score on the rubrics. Rather, a condition code is given alerting the teacher candidate that there was an issue and that he/she needs to resubmit the video(s), which, in turn, means that the entire portfolio would not be scored, requiring a resubmission.

Teacher candidates must be aware that the video clips have to be "continuous and unedited, with no interruption in events" (Stanford Center for Assessment, Learning, \& Equity, 2015, p. 19). Teacher candidates are prohibited from slicing or edited the video in any way. Additionally, titles and credits are not allowed (Stanford Center for Assessment, Learning, \& Equity, 2015). Importantly, teacher candidates must include interactions between the teacher candidate and learners as well as learner-to-learner interactions.

\section{Peer Review to Avoid Condition Codes}

As eluded to earlier, creating a high-stakes assessment such as edTPA can be an anxiety-filled moment for teacher candidates, and perhaps even for program faculty members. Thus, it is important for all involved (e.g., university supervisors, cooperating teachers) to provide assistance to teacher candidates in order to avoid receiving any condition codes that would render the entire portfolio unable to be scored, requiring resubmission. Each time a portfolio has to be revised and resubmitted, either one task or all three, it costs an additional $\$ 100$ per task, $\$ 300$ if the entire portfolio must be resubmitted. The authors recommend having teacher candidates peer review the portfolios prior to submission by opening each file and making sure the videos play and that the commentaries can be read. edTPA rules stipulate that peer reviewers may only check for technical issues, such as a corrupt file or a file that is formatted incorrectly. 
edTPA is a high-stakes assessment and receiving a condition code for even one video malfunction forces teacher candidates to resubmit one or more of the tasks at an additional cost. As noted by Hildebrandt and Swanson (2016), many academic semesters are based on 14 or 15 week semester, and it is wise for teacher candidates to complete and submit the official edTPA portfolio by week 10 in order to have extra time if needed to rework section(s) need to be resubmitted for scoring in order to receive a passing score by the end of the semester. Official scoring often takes several weeks and can potentially create timing issues for program completion and teacher certification. The authors recommend viewing Pearson's (2019) schedule for submission to gauge an appropriate timeline for submission.

\section{CONCLUSION}

The passing and implementation of the ESEA legislation continues to impact American education. The law's focus on setting high standards for academic performance has changed the educational landscape in the US significantly. Coupled with the paradigm shift toward CLT with the concomitant emphases on TL use and real-world tasks in the WL classroom, evaluation of student progress in language learning and eventual development of TL proficiency have received renewed focus and attention. The ability of teachers to facilitate language learning in a CLT environment is based now on learner outcomes as demonstrated on student proficiency assessments, such as the IPA. In order to prove their professional competency and garner certification and/or licensure, teacher candidates are including use of IPAs as part of their edTPA portfolio to illustrate their students' progress toward TL proficiency. It is, therefore, ever-more important that teacher educators, school district officials, and teacher candidates become knowledgeable about edTPA requirements and what constitutes a high-scoring edTPA portfolio in WLs. Research shows the criticality of creating and submitting quality videos as part of the edTPA portfolio (Goulette \& Swanson, 2017) as well as using IPAs to document learner abilities in the TL (Swanson, \& Goulette, 2018). With the widespread acceptance of edTPA in approximately $80 \%$ of the US, it is important that WL teacher educators guide pre-service teachers carefully in order to successfully create a quality and passing portfolio that indicates, at the very least, the professional capabilities sought after in a WL teacher candidate. 


\section{REFERENCES}

American Association for Colleges of Teacher Education. (2016). Participation map. Available from, http://edtpa.aacte.org/state-policy

American Council on the Teaching of Foreign Languages. (2010). Position statement on use of the target language in the classroom. Retrieved May 202019 from, https://www.actfl.org/news/positionstatements/use-the-target-language-the-classroom

Baecher, L. H., McCormack, B., \& Kung, S. (2014). Supervisor use of video as a tool in teacher reflection. The Electronic Journal for English as a Second Language, 18(3), 1-17.

Cochran-Smith, M. (2000). The questions that drive reform. Journal of Teacher Education, 51, (5), 331333.

Cochran-Smith, M. (2001). Constructing outcomes in teacher education. Education Policy Analysis Archives, 9(11), 1-56.

Cox, T. L., Malone, M. E., \& Winke, P. (2018). Future directions in assessment: Influences of standards and implications for language learning. Foreign Language Annals, 51, 104-115.

Danielowich, R. M. \& McCarthy, M. J. (2013). Teacher educators as learners: How supervisors shape their pedagogy by creating and using classroom videos with their student teachers. Action in Teacher Education, 35, 147-164.

Darling-Hammond, L. (2012). The right start: Creating a strong foundation for the teaching career. Phi Delta Kappan, 94, 8-13.

Elementary and Secondary Education Act of 1965, Pub. L. No. 89-10, 79 Stat. 27.

Gatbonton, E. (1999). Investigating experienced ESL teachers' pedagogical knowledge. The Modern Language Journal, 83(1), 35-50.

Georgia Professional Standards Commission. (2014). Understanding the 2014 educator certification rule. Available from,

http://www.gapsc.com/Commission/policies_guidelines/Downloads/2014EducatorCertificationRuleChan ges.pdf

Georgia Professional Standards Commission. (2015). edTPA standard setting decision. Available from, http://www.gapsc.com/Downloads/edTPA_Standard_Setting_Decision_071015.pdf

Goe, L., Bell, C., \& Little, O. (2008). Approaches to evaluating teacher effectiveness: A research synthesis. Washington, DC: National Comprehensive Center for Teacher Quality.

Goulette, E., \& Swanson, P. (2017). Video considerations for the world language edTPA. In M. KhosrowPour (Ed.), Encyclopedia of information science and technology (4th ed.) (pp. 7682-7691). Hershey, PA: IGI Global. 
Hammadou-Sullivan, J. (2004). Identifying the best foreign language teachers: Teacher standards and professional portfolios. The Modern Language Journal, 88(3), 390-402.

Hildebrandt, S., \& Swanson, P. (2014). World language teacher candidate performance on edTPA: An exploratory study. Foreign Language Annals, 47(4), 576-591.

Hildebrandt, S., \& Swanson, P. (2016). Understanding the world language edTPA: Research-based policy and practice. Charlotte, NC: Information Age Publishers).

Horwitz, E. K. (2010). Foreign and second language anxiety. Language Teaching, 43(2), 154-167. https://doi.org/10.1017/S026144480999036X

Illinois State Board of Education. (2012). Memo. Available from, http://www.isbe.state.il.us/licensure/pdf/higher-ed/edTPA/edTPA-summary1212.pdf

Kaplan, C. S. (2016). Alignment of world language standards and assessments: A multiple case study. Foreign Language Annals, 49(3). 502-529.

DOI: $10.1111 /$ flan.12220

Kissau, S., \& Adams, M. J. (2016). Instructional decision making and IPAs: Assessing the modes of communication. Foreign Language Annals, 49(1), 105-123.

DOI: 10.1111/flan.12184

Larsen-Freeman, D. \& Tedick, D. J. (2016). Teaching world languages: Thinking differently. In D. H. Gitomer \& C. A. Bell (Eds.) Handbook of research on teaching (pp. 1335-1388). Washington, DC: American Educational Research Association.

Lee, J. F., \& VanPatten, B. (2003). Making communicative language teaching happen. $2^{\text {nd }}$ Ed. New York: McGraw-Hill.

Martel, J. (2017). Is the field of foreign language education disposed to change? The Modern Language Journal, 101(2), 431-433.

Martel, J., \& Bailey, K. M. (2016). Instructors' attitudes toward IPA implementation in a postsecondary intensive summer language program. Foreign Language Annals, 49(3), 530-543.

DOI: $10.1111 /$ flan. 12210

McInnis, C. E., \& Donoghue, E. E. (1980). A comparative study of the relative effectiveness of two different second language training programs. Canadian Journal of Psychology/Revue canadienne de psychologie, 34(4), 314-327.

Muijs, D. (2006). Measuring teacher effectiveness: Some methodological reflections. Educational Research and Evaluation: An International Journal on Theory and Practice, 12, 53-74.

National Commission on Excellence in Education. (1983). A nation at risk: the imperative for educational reform: a report to the Nation and the Secretary of Education. United States Department of Education. Washington, D.C.: The Commission: [Supt. of Docs., U.S. G.P.O. distributor].

Nunan, D. (1991). Communicative tasks and the language curriculum. TESOL Quarterly, 25, 279-95. 
Okraski, C. V., \& Kissau, S. P. (2018). Impact of content-specific seminars on candidate edTPA preparation and performance. Foreign Language Annals, 51(3), 685-705.

https://doi.org/10.1111/flan.12351

Olshtain, E., \& Kupferberg, I. (1998). Reflective-narrative discourse of FL teachers exhibits professional knowledge. Language Teaching Research, 2(3), 185-202

Pearson. (2014). Recommended video format and settings. Available from, https://www.edtpa.com/.../RecommendedVideoFormatsandSettings.pdf

Pearson. (2019). edTPA Submission and reporting dates. Available from, https://www.edtpa.com/PageView.aspx?f=GEN_ScoreReportDates.html

Renaissance Partnership for Improving Teacher Quality. (2002). Teacher work sample: Performance prompt, teaching process standards, scoring rubrics. Bowling Green, KY: Author,

Rosenbusch, M. H. (2005). The no child left behind act and teaching and learning languages in the U.S. Schools. The Modern Language Journal, 89, 250-261.

Rosenbusch, M. H., \& Jensen, J. (2004). Status of foreign language programs in NECTFL states. NECTFL Review, 56, 26-37.

Sato, M. (2014). What is the underlying conception of teacher of the edTPA? Journal of Teacher Education, 1-14. Available from, http://jte.sagepub.com/content/early/2014/07/09/0022487114542518

Shrum, J. L., \& Glisan, E. W. (2016). Teacher's handbook: Contextualized language instruction. Boston: Cengage Learning.

Stanford Center for Assessment, Learning, and Equity. (n.d.). About edTPA. Available from, https://edtpa.aacte.org/about-edtpa

Stanford Center for Assessment, Learning, and Equity. (2013). 2013 edTPA field test: Summary report. Stanford, CA: Stanford University. Available from, http://edtpa.aacte.org/news-

area/announcements/edtpa-summary-report-is-now-available.html

Stanford Center for Assessment, Learning, and Equity. (2015a). edTPA world language assessment handbook. Stanford, CA: Stanford University.

Stanford Center for Assessment, Learning, and Equity. (2019a). Recommended professional performance standard. Stanford, CA: Stanford University. Available from, https://www.edtpa.com/PageView.aspx?f=GEN_PerformanceStandard.html

Stanford Center for Assessment, Learning, and Equity. (2019b). edTPA for Georgia. Stanford, CA: Stanford University. Available from, https://www.edtpa.com/PageView.aspx?f=GEN_Georgia.html

Strasheim, L. A. (1967). Target: methods; a program for the improvement of foreign language teacher preparation programs in Indiana colleges and universities, 1965-1967. Bloomington, IN: Indiana University. (ED037139). 
Swanson, P. (2012). Second/foreign language teacher efficacy: Multiple factors and their relation to professional attrition. Canadian Modern Language Review, 68(1), 78-101. DOI: 10.3138/cmlr.68.1.078

Swanson, P. (2017). The future of K-12 teacher education: Spanish and Portuguese. Hispania, 100(5), 261-267.

Swanson, P., \& Goulette, E. (2018). The criticality of the integrated performance assessment in the world language edTPA. In P. Swanson \& S. A. Hildebrandt (Eds.), Researching edTPA Problems and Promises: Perspectives from ESOL, English, and wl teacher education (pp.). Charlotte, NC: Information Age Publishing.

Swanson, P., \& Hildebrandt, S. A. Communicative learning outcomes and world language edTPA: Characteristics of high-scoring portfolios. Hispania, 100(3), 331-347.

Tripp, T. R. \& Rich, P. J. (2012). The influence of video analysis on the process of teacher change. Teaching and Teacher Education, 28, 728-739.

Tum, D. O. (2015). Foreign language anxiety's forgotten study: The case of the anxious preservice teacher. TESOL Quarterly, 49(4), 627- 658.

U.S. Department of Education. (2004, March). New no child left behind flexibility: Highly qualified teachers. Washington, DC: U.S. Department of Education. Available from, http://www.ed.gov/nclb/methods/teachers/hqtflexibility.html

U.S. Department of Education. (2002). No Child Left Behind Act of 2001, Pub. L. No. 107-110, § 115, Stat. 1425. Available from, http://www2.ed.gov/ policy/elsec/leg/esea02/107-110.pdf

U.S. Department of Education. (2009). Race to the top executive summary. Available from, http://www2.ed.gov/programs/racetothetop/executive-summary.pdf

U.S. Department of Education. (2014). Improving teacher preparation: Building on innovation. Available from, http://www2.ed.gov/documents/teaching/teacher-prep.pdf

Wright, A. W., Knight, P. T., \& Pomerleau, N. (1999). Portfolio people: Teaching and learning dossiers and innovation in higher education. Innovative Higher Education, 24(2), 89-103.

Zapata, G. C. (2016). University students' perceptions of integrated performance assessment and the connection between classroom learning and assessment. Foreign Language Annals, 49(1), 93-104.

\section{ADDITIONAL READINGS}

Adair-Hauck, B, Glisan, E. W., \& Troyan, F. J. (2014). Implementing integrated performance assessment. Alexandria, VA: ACTFL.

Adair-Hauck, B, Glisan, E. W., Koda, K., \& Swender, E. B. (2006). The integrated performance assessment (IPA): Connecting assessment to instruction and learning. Foreign Language Annals 39(3):359 - 382. DOI: 10.1111/j.1944-9720.2006.tb02894.x

Hildebrandt, S., \& Swanson, P. (2016). Understanding the world language edTPA: Research-based 
policy and practice. Charlotte, NC: Information Age Publishers.

Swanson, P., \& Hildebrandt, S. A. (Eds.) (2018). Researching edTPA Problems and Promises:

Perspectives from ESOL, English, and World Language Teacher Education. Charlotte, NC: Information Age Publishing.

\section{KEY TERMS AND DEFINITIONS}

- Communicative Language Teaching Approaches: In a paradigm shift away from the four skills (i.e. reading, writing, listening, and speaking), the communicative approaches are based on the idea that learning language takes place successfully through communicating for the purpose of gaining real meaning.

- edTPA: A nationally-available subject-specific performance-based assessment in 27 content areas that is now in place in more than 40 states and 800 teacher preparation programs in the U.S. as a method to measure teacher candidates' developing skills and knowledge via a portfolio.

- Elementary and Secondary Education Act of 1965: A landmark federal law that funded primary and secondary education and stressed high standards and accountability. As mandated, funds are authorized for a variety of initiatives such as professional development, instructional materials, and resources to support educational programs. The government reauthorizes the act every five years sometimes under new titles such as No Child Left Behind and Race to the Top.

- Integrated Performance Assessment (IPA): A standards-based and performance-based assessment that contains three tasks, aligned with a common central focus, that emphasizes each of the three modes of communication: interpersonal, interpretive, and presentational.

- Modes of Communication: Based on ACTFL's notion that communication in a language takes place in three modes: interpersonal, interpretive, and presentational.

- Teacher candidates: Also known as pre-service teachers, this term is used to describe individuals who are enrolled in a teacher preparation program and working toward teacher certification. They complete state requirements for certification such as supervised field-based teaching experiences (a.k.a., student teaching). 